HSTC Bulletin

Journal of the History of Canadian Science, Technology and Medecine

hstc

Revue d'histoire des sciences, des techniques et de la médecine au Canada

bulletin

\title{
Sources in the History of Canadian Technology \#3
}

\section{Norman R. Ball}

Volume 2, numéro 3 (7), may 1978

URI : https://id.erudit.org/iderudit/1082241ar

DOI : https://doi.org/10.7202/1082241ar

Aller au sommaire du numéro

Éditeur(s)

HSTC Publications

ISSN

0228-0086 (imprimé)

1918-7742 (numérique)

Découvrir la revue

Citer cet article

Ball, N. R. (1978). Sources in the History of Canadian Technology \#3. HSTC

Bulletin, 2(3), 5-6. https://doi.org/10.7202/1082241ar d'utilisation que vous pouvez consulter en ligne.

https://apropos.erudit.org/fr/usagers/politique-dutilisation/ 
SOURCES IN THE HISTORY OF CANADIAN TECHNOLOGY

Norman R. Ball

Whenever two or three individuals interested in the history of Canadian science and technology get together there is a good chance that they will differ on whether or not there is anywhere to publish material in the field. While there is something to be said on both sides the greater scarcity appears to be that of people trying to publish, not places to publish. This is particularly the case in the history of Canadian engineering and technology. In the list of sources in this issue a number of the articles are drawn from two journals interested in receiving Canadian material: IA. The Journal of the Society for Industrial Archeology, and the Bulletin of the Association for Preservation Technology.

Although IA was intended to publish twice yearly it only appears annual $\overline{l y}$. There were certain problems but the new editor may get it up to its target. IA publishes articles, discussions, book reviews, and short notes relating to industrial archeology. For an understanding of just how broad a range this covers, one should consult back issues. The Society for Industrial Archeology also publishes a newsletter containing short articles, news and good bibliographical notes, much of which relates to Canada. It is the best historical newsletter that the author is acquainted with.

Enquires regarding IA should be sent to

Dr. Michael Robbins

Editor IA

510 Broome St.

\#4-E

New York, N.Y.

10013.

The Association for Preservation Technology is a rather unusual organization which more people should know about. Its primary aim is the study of technology as it relates to preservation. This aim can be interpreted rather broadly and it is this which makes the Bulletin such interesting reading. Some of the articles deal with the application of modern technology, such as the uses of X-rays in the examination of historic structures, or the monitoring and assessment of the effects of airborne pollutants on the artistic fabric of historic structures. But since its inception the Bulletin has reflected the view that if one is to preserve the physical remains of the past one must understand the technology associated with producing it; hence their interest 
in historical articles in a wide number of areas related to building, architecture, gardening, and other areas covered by the Bulletin. The Bulletin is published quarterly, two issues from the American editor and two from the Canadian, making it somewhat more international than most international journals. The Canadian editors--Susan Buggey, editor in chief, Norman R. Ball, technical editor--are interested in receiving historical papers suitable for publication. Write to

\author{
Ms. Susan Buggey \\ Editor APT Bulletin \\ 195 Clearview Avenue \\ Apt. 1521 \\ ottawa, Ontario \\ KIZ $6 S 1$
}

DIRECTORY OF HISTORIANS OF CANADIAN SCIENCE AND TECHNOLOGY ANNUAIRE DES HISTORIENS D'HISTOIRE DES SCIENCES ET DE LA TECHNOLOGIE CANADIENNES

1978

BALL, Norman, Public Archives of Canada; 51 Sherbrooke St., 233-8536; Early Agricultural and Industrial Technology; Engineering History; Archives.

BENNETT, Gordon, Research Div. National Historic Parks and Sites Branch Parks Canada; 41 Findlay Ave. Ottawa; 236-9055 M.A. (New Brunswick). Transportation in the Yukon.

BÉRUBÉ, André, Parcs-Canada; 16 St-Dominique, Hull, Québec; 770-8685 (996-4971); M.A. (Ottawa). Histoire des techniques artisanales et industrielles. Histoire de la sidérurgie.

BOIVIN, Bernard, Central Experimental Farm, Argiculture Canada; L.Sc. (Montréal), Ph.D. (Harvard). Bibliography, biography, and history of botany.

BOUSE, David, Restoration Services Div. Indian and Northern Affairs; 54 Somerset W., Ottawa; 232-0728 (996-406); B.Arch. (Nebraska). Recording methods (techniques and application for industrial archaeology.

BOWLER, Peter J., Dept. History, University of Winnipeg; 248 McIntosh Ave., Winnipeg, Man.; 667-5522; Ph.D. (Toronto). Geology in Canada. Scientific societies.

CORNELL, John. F., Grad. Student, McGill University; 1754 Cedar Ave., Apt. 4; 937-6751; B.A. (McGill). Villiam Dawson and evolution. 